\title{
FLUCTUATION OF Doleschallia bisaltide LARVAE (LEPIDOPTERA: NYMPHALIDAE) ON CARICATURE-PLANT (Graptophyllum pictum)
}

\author{
M. Bakti Samsu Adi, Dian Susanti, \& Nur Rahmawati Wijaya \\ Medicinal Plant and Traditional Medicine Research and Development Center, Indonesia \\ Jl. Raya Lawu No.11 Tawangmangu, Karanganyar, Jawa Tengah 57792 \\ E-mail: adi.b2p2to2t@gmail.com
}

Manuscript received: 13 April 2020. Revision accepted: 11 September 2020.

\begin{abstract}
Fluctuation of Doleschallia bisaltide larvae (Lepidoptera: Nymphalidae) on caricature-plant (Graptophyllum pictum). Caricature-plant cultivation is often damaged due to the attack of Doleschallia bisaltide larvae. High reproduction ability of D. bisaltide is a serious problem that need to be managed, therefore it will not inflict a financial losses. This study was aimed to determine the fluctuation of D. bisaltide larval population in the caricature-plant plantation in Kalisoro, Tawangmangu. The observations were carried out with a survey method on five observation plots for seven months from March to September 2018. The data were analyzed by descriptive statistics and the Spearman rank correlation coefficient test. The results showed that the population structure was changed during the observations with the highest larval population in May. The results of Spearman rank correlation coefficient test showed significant and positive correlation between third, fourth, and fifth instars larvae with the rainfall. The control of $D$. bisaltide can not only depend on the presence of natural enemies, therefore control interventions were needed especially at a suitable time and environment whe the population increased.
\end{abstract}

Key words: butterfly, Doleschallia bisaltide, fluctuation, Graptophyllum pictum, population

\section{INTRODUCTION}

Caricature-plant, Graptophyllum pictum (L.) Griff (Acanthaceae: Graptophyllum) is an important medicinal plant that widely used in Indonesia to treat hemorrhoids (Astana \& Nisa, 2018; Sya' haya \& Iyos, 2016), swollen and constipation (Widiyastuti et al., 2012). It is also has an effect as an analgesic (Lestari et al., 2015; Nhestricia et al., 2019). Related to its efficacy, caricature-plant began to be developed and cultivated as an effort to fulfill raw materials for traditional medicine. The cultivation of caricature-plant is still constrained by pests, especially Doleschallia bisaltide Cramer (Lepidoptera: Nymphalidae) as caricature-plant is one of D. bisaltide host plant (Nitin et al., 2018; Orr $\&$ Kitching, 2010). This butterfly become the main pest of caricature-plant due to its ability to lay more than 20 eggs on one leaf (Sartiami et al., 2009). Its high reproductive ability potentially causing losses in caricature plant cultivation, because it increases attacks on leaves, which used as raw material for traditional medicines. $D$. bisaltide can be a serious threat to caricature-plant cultivation and cause losses up to $70 \%$ (Lestari et al., 2015).
D. bisaltide is also known as Australian leafwing or autumn leaf butterfly. $D$. bisaltide can live at an altitude of 0-1400 meters above sea level (Hoskins, 2012). Its presence is influenced by environmental conditions and the availability of food for both the larvae and the imago (Lestari et al., 2020). Geographically, this butterfly can be found in South Asia, South East Asia, India, and Australasia (Nitin et al., 2018; Varshney \& Smetacek, 2015). Currently, pest control in caricatureplant is not well developed yet. This due to the plants are currently categorized as weed, not food or industrial crops. This study was aimed to determine the monthly fluctuations of $D$. bisaltide larvae, so that the information obtained can be used in integrated pest control in caricature-plant's cultivation.

\section{MATERIALS AND METHODS}

Research Site. The study was conducted at dry season from March to September 2018 in the Kalisoro garden, the Medicinal Plant and Traditional Medicine Research and Development Center, Tawangmangu. It is located at an altitude of 1200 meters above sea level, at coordinates $7^{\circ} 39^{\prime} 50.7^{\prime \prime} \mathrm{S} ; 111^{\circ} 08^{\prime} 02.4^{\prime \prime} \mathrm{E}$. 
Procedures. Observations were conducted by survey method in the $56 \mathrm{~m}^{2}$ area planted with caricature-plants. The larval population of $D$. bisaltide was calculated at one-month intervals. One-month intervals were determined so that the same individuals were not resampled. It was based on the life cycle of $D$. bisaltide (Figure 1) which to pupate takes about 25 days after hatching (Handayani et al., 2019). Observations were made on five plots $(1 \times 1) \mathrm{m}^{2}$. The eggs and larvae in the plot were counted according to the growth phase. The environmental data measured are humidity, temperature, light intensity, and rainfall. Humidity and temperature were measured with the thermohygrometer Comet D3120, light intensity was measured by the luxmeter Mastech 6612, while rainfall data were obtained from the ombrometer which was recorded every day at the study site (Table 1).

Data Analysis. Environmental and population data were analyzed by Spearman rank correlation coefficient to see the correlation level of each factor. Spearman rank correlation coefficient test was used to determine whether changes in environmental factors correlated with changes in larval populations that attack caricatureplants leaves.

\section{RESULTS AND DISCUSSION}

Population structure of eggs and larvae of D. bisaltide (Figure 3) which has been observed for seven months from March to September 2018 in caricature-plant field is shown in Figure 2. Based on the growth phase from eggs, first to fifth instars larvae (Figure 4), the composition of the larval population was changed dynamically. Changes occurred in the population pattern were influenced by the presence of host plants and natural enemies such as predators and parasitoids (Hendrival et al., 2011). Caricature-plants cropping throughout the year in the same location without applying crop rotation will cause larva host plants available continuously.

Based on the number of eggs found in dry season (Figure 2), it appears that $D$. bisaltide's mate and reproduction occurred in the whole months. Eggs were found until May quite a lot, and then decreased afterwards. Observations in the dry season showed that there were number of eggs found in damaged condition. The damaged eggs in May were caused by a parasitoid that identified as Telenomus sp. This parasitoid uses insect eggs as a host in its reproduction process (Ballal, 2013; Mardiningsih et al., 2010; Shumakov, 1976).

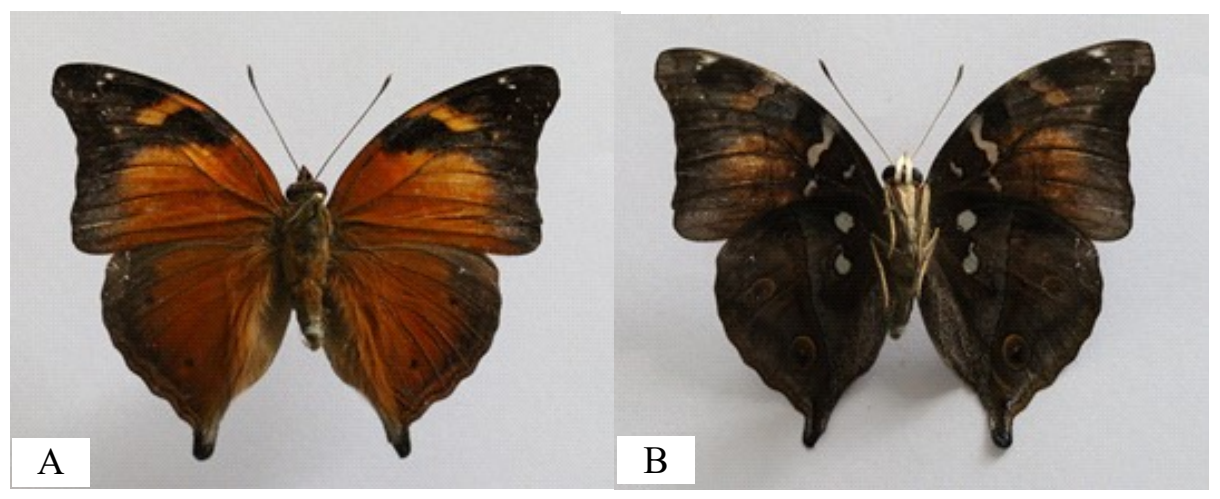

Figure 1. Doleschallia bisaltide Imago. (A) Top view; (B) Bottom view.

Table 1 . The average environment condition of observed area

\begin{tabular}{lrrrrrrr}
\hline \multicolumn{1}{c}{ Parameters } & March & \multicolumn{1}{c}{ April } & \multicolumn{1}{c}{ May } & June & July & August & September \\
\hline Temperature $\left({ }^{\circ} \mathrm{C}\right)$ & 24.0 & 25.2 & 25.0 & 24.7 & 21.8 .0 & 24.3 & 21.4 \\
Humidity (\%) & 67.0 & 67.0 & 74.0 & 73.0 & 71.0 & 73.0 & 68.0 \\
Rainfall (mm) & 538.6 & 152.4 & 247.0 & 13.4 .0 & 0.0 & 0.0 & 4.2 \\
Top light intensity (lux) & 436.0 & 640.0 & 334.0 & 372.0 & 440.0 & 696.0 & 849.0 \\
Bottom light intensity (lux) & 168.6 & 185.0 & 168.7 & 173.6 & 101.9 & 177.0 & 202.4 \\
\hline
\end{tabular}




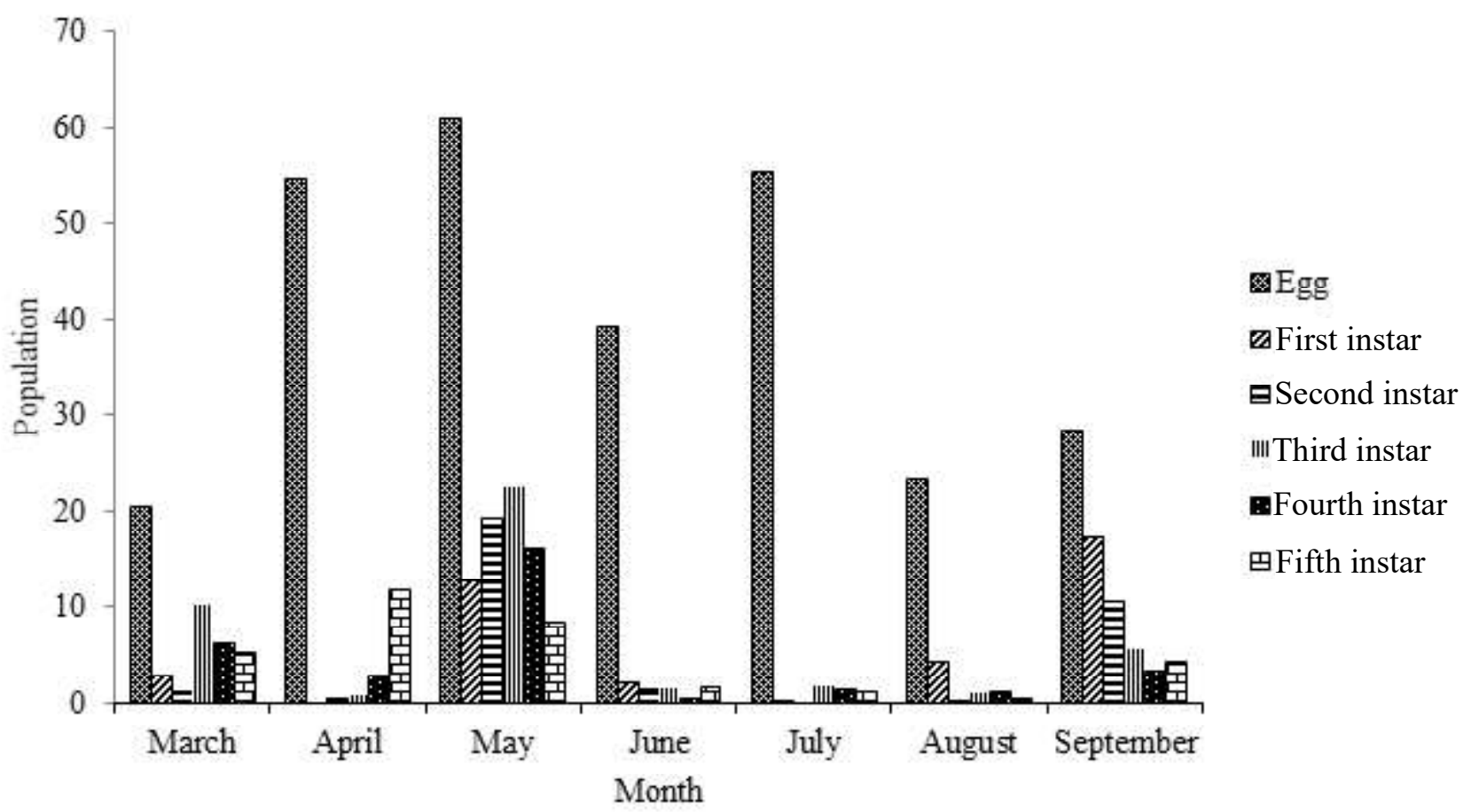

Figure 2. Fluctuations of egg and larval populations of Doleschallia bisaltide per month.
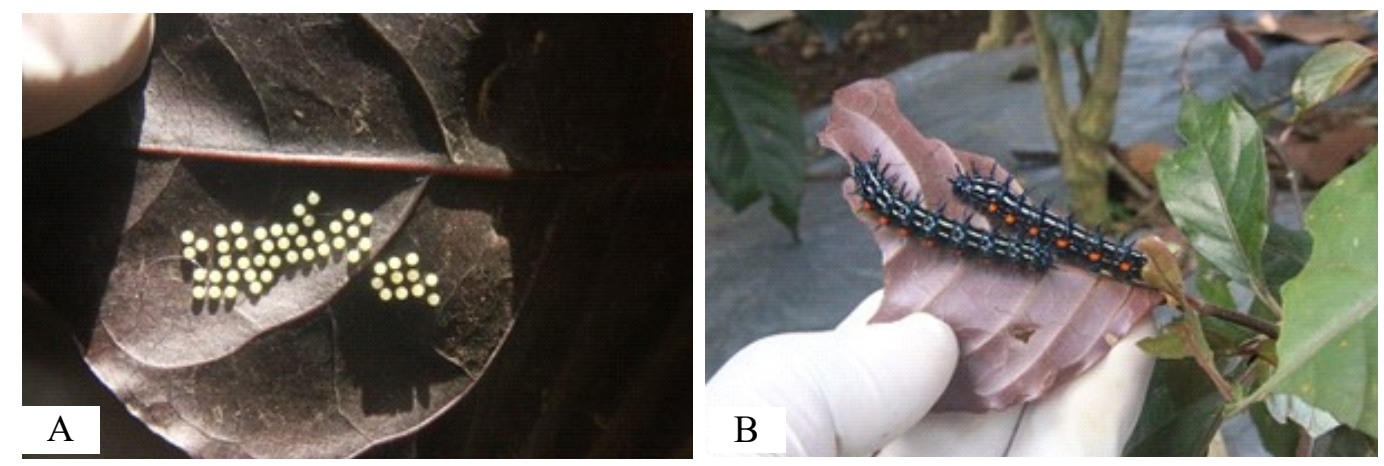

Figure 3. Doleschallia bisaltide on Graptophyllum pictum. (A) Eggs; (B) Larvae.
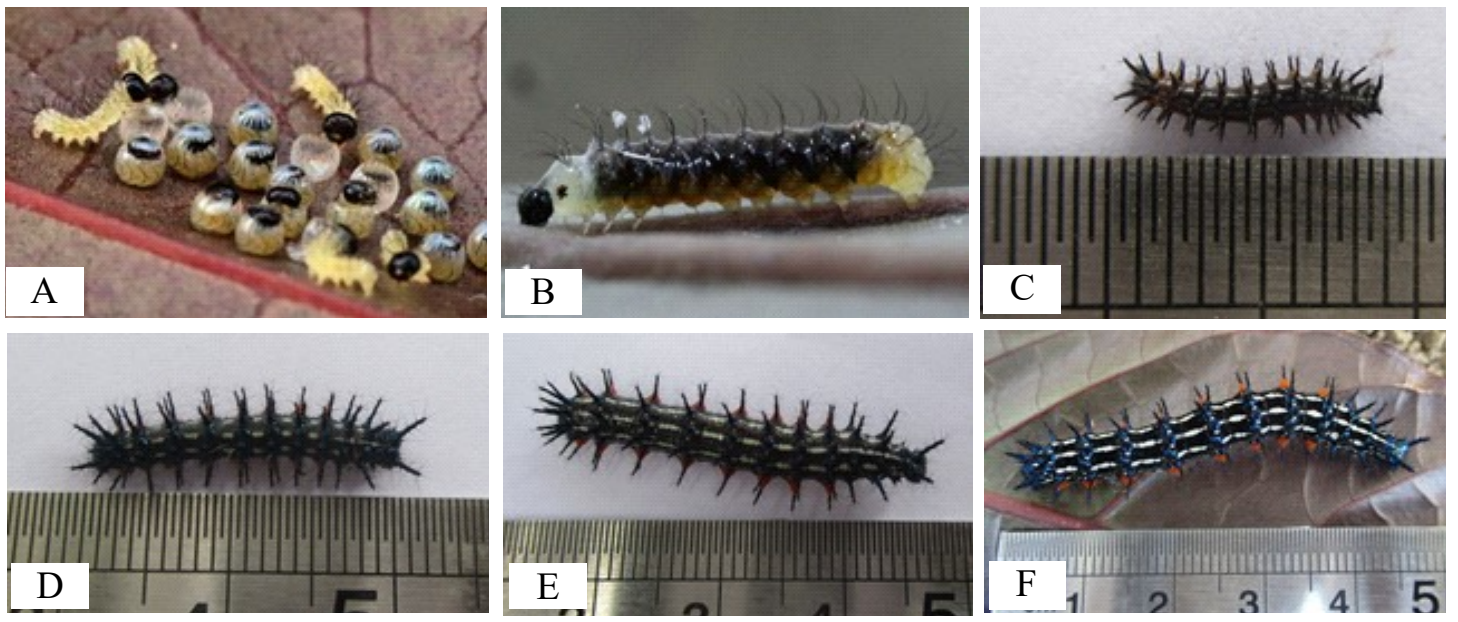

Figure 4. Larva Doleschallia bisaltide instar stages based on size and body shape changes. (A) New born; (B) First instar; (C) Second instar; (D) Third instar; (E) Fourth instar; (F) Fifth Instar. 
Considering that the Telenomus sp. population is not observed, it is necessary to carry out further research on its effectiveness in reducing the number of $D$. bisaltide eggs. The presence of eggs attacked by parasitoids shows their potential to be used in pest control, especially before the host plant was damaged by pest larvae.

Meanwhile, the fluctuation of $D$. bisaltide larvae was also quite dynamic. The highest population was occurred in May, except for the fifth instar as shown in Figure 2. The larval population decreased in June and an increase occurred in September. It can also be seen in the graph that there were several months where the population of second instar larvae is so low that they are not found at all. In addition to environmental factors, these larvae are cannibalistic where the smaller larvae preyed upon by larger larvae (James, 2017). In larger instars, the presence of Apanteles sp. as parasitoids which attacks larvae also plays a role in reducing the number of larvae (Gupta et al., 2016; Hasanah et al., 2018; Mardiningsih et al., 2010; Muru et al., 2017). At the time of this study, the smallest larvae found to be attacked by this parasitoid were the fourth instar. Hasanah et al. (2018) reported that Apanteles sp. attacks larvae at third instar and even though these larvae are already infected, they are still actively moving.

Based on population fluctuation, it can be seen that the overall success rate of $D$. bisaltide to reach the fifth instar is quite low. The larvae that reach the fifth instar were always fewer than the number of eggs that found. These conditions indicated that, there has been a natural process of controlling $D$. bisaltide populations in caricature-plant gardens.

Based on Figure 2, it is clear that the peak of the population was reached in May. On the following month, the population was decreases until August, except for the first instar. After August, there has been an increase in growth at all instar levels. This is due to environmental factors that increasingly support the growth of $D$. bisaltide larvae, one of which is the rarity of parasitoids investing in eggs.

The Spearman rank correlation coefficient test between larval populations and environmental factors is presented in Table 2. The test results show that there is a strong and significant in-line correlation at the 0.01 level between the third, fourth, and fifth instars on rainfall. This means that when there is a decrease in rainfall, the larval population of the three instars also decreases significantly, and vice versa. However, even though it is strongly correlated, the decline in the larval population is not necessarily caused by rainfall, because the Spearman rank correlation coefficient test cannot show a causal relationship.

Low larval populations in June and July indicated that the eggs were failed to hatch or larvae were unable

Table 2. Spearman rank correlation coefficient analysis

\begin{tabular}{llcrrrr}
\hline \multicolumn{1}{c}{ Phase } & \multicolumn{1}{c}{ Test } & Temperature & Humidity & Rainfall & $\begin{array}{c}\text { Top light } \\
\text { intensity }\end{array}$ & $\begin{array}{c}\text { Bottom light } \\
\text { intensity }\end{array}$ \\
\hline \multirow{2}{*}{ Egg } & Correlation Coefficient & 0.06 & 0.13 & -0.04 & -0.16 & -0.14 \\
& Sig. (2-tailed) & 0.74 & 0.45 & 0.82 & 0.36 & 0.41 \\
& Correlation Coefficient & -0.20 & 0.28 & 0.21 & -0.09 & 0.18 \\
First & Sig. (2-tailed) & 0.25 & 0.11 & 0.22 & 0.62 & 0.31 \\
Second & Correlation Coefficient & 0.11 & $0.35^{*}$ & $0.34^{*}$ & -0.27 & 0.21 \\
Instar & Sig. (2-tailed) & 0.54 & 0.04 & 0.05 & 0.11 & 0.23 \\
Third & Correlation Coefficient & 0.07 & 0.10 & $0.54^{* *}$ & $-0.37^{*}$ & -0.22 \\
Instar & Sig. (2-tailed) & 0.69 & 0.55 & 0.00 & 0.03 & 0.20 \\
Fouth & Correlation Coefficient & 0.29 & 0.01 & $0.54^{* *}$ & $-0.36^{*}$ & -0.19 \\
Instar & Sig. (2-tailed) & 0.10 & 0.98 & 0.00 & 0.03 & 0.28 \\
Fifth & Correlation Coefficient & 0.30 & $-0.36^{*}$ & $0.44^{* *}$ & -0.06 & 0.16 \\
Instar & Sig. (2-tailed) & 0.08 & 0.03 & 0.01 & 0.75 & 0.36 \\
\hline
\end{tabular}

The correlation coefficient level: $0.00-0.20=$ very weak; $0.21-0.40=$ weak; $0.41-0.70=$ strong; $0.71-0.90=$ very strong; $0.91-0.99=$ very strong at all; $1=\operatorname{perfect}\left(\right.$ Sujarweni, 2014). ${ }^{* *}$ : Correlation is significant at the 0.01 level (2-tailed). *: Correlation is significant at the 0.05 level (2-tailed). 
to develop. This is different from the research of Hasanah et al. (2018) which stated that, the biggest cause of eggs failing to hatch in November-December is rainfall (49.54\%) and predators $(41.36 \%)$ because environmental data (Table 1) shows rainfall very low in June to September. The decrease in the number of eggs and larvae population on the dry season is influenced by environmental factors and the presence of natural enemies. Riyanto et al. (2011) said that parasitoid abundance in the dry season is higher than the rainy season. Parasitoid abundance is closely related to temperature and target insect populations in the dry season. Parasitoid is more effective in carrying out metabolic activities at higher temperatures which means that high temperatures can accelerate the activity of parasitoids investing in abundant host eggs. Mortality factors caused by parasitoids only occurs at the stage of eggs and larvae.

However, it is not enough to control the number of pest populations so as not to interfere with the caricature-plant cultivation process. Intervention efforts are still needed to control the growth of $D$. bisaltide populations. Sustainable biological control carried out by using natural enemies, natural insecticides, as well as by improving the macro and microenvironments of plants.

Utilization of the parasitoid Telenomus sp. as a natural enemy in biological control as practiced by Barloggio et al. (2015) appears effective, because the damage caused by pests was minimized. The parasitoids usage as natural enemies must consider the fluctuations and seasonal patterns of the main agent and its competitors, so the biological control process is effective (Frago et al., 2012). Also, habitat engineering needed so that parasitoids can survive and develop naturally, especially related to the food needs of these natural enemies (Rizali et al., 2018).

Environmental improvements done by regulating cropping patterns, spacing, and crop rotation to prevent pests movement from one plant to another, so that pest attacks intensity could be decreases (Suryadi et al., 2017). Fauriah \& Anas (2019) in their research showed that at a square planting system of maize has a lower pest attacks than the legowo system. Pest control can be maximized by combining with intercropping and crop rotation systems. D. bisaltide larvae control can be done by intercropping with refugia plants, or by adjusting the cropping pattern through crop rotation, namely complete plant replacement starting in the month where the pest population is highest. Control can also be done by adjusting the planting time and harvest schedule according to the time before the $D$. bisaltide population increases based on the graph of population fluctuation results of the study.

D. bisaltide control can further be done using natural pesticides. Natural insecticides used to control pests with consideration of effectiveness and without residues produced by chemical pesticides. Research conducted by Balfas et al. (2010) using oil of several medicinal and aromatics plants against $D$. bisaltide on a laboratory scale, shows that babandotan (Ageratum conyzoides L.) oil has the potential to control pests.

An understanding of the growth patterns of D. bisaltide both individually, and in population in response to environmental variations is very important in determining integrated pest management methods (IPM). Population D. bisaltide in caricature-plant garden dynamically fluctuate from month to month. There are environmental factors both biotic and abiotic that influence. Pest control of $D$. bisaltide larvae especially in April to May must be carried out with intensive intervention compared to June to August. Natural enemies can be used to control D. bisaltide, especially before larvae develop, in combination with increasing spacing, planting refugia plants, harvest scheduling, or with other methods that are in accordance with $D$. bisaltide behavior in an integrated pest management effort.

\section{CONCLUSION}

An understanding of the growth patterns of $D$. bisaltide both individually, and in population in response to environmental variations is very important in determining integrated pest management methods (IPM). Population of D. bisaltide in caricature-plant garden dynamically fluctuate from month to month. There are environmental factors both biotic and abiotic that influence. Pest control of $D$. bisaltide larvae especially in April to May must be carried out with intensive intervention compared to June to August. Natural enemies can be used to control D. bisaltide, especially before larvae develop, in combination with increasing spacing, planting refugia plants, harvest scheduling, or with other methods that are in accordance with $D$. bisaltide behavior in an integrated pest management effort. 


\section{ACKNOWLEDGMENTS}

The authors thanks the Head of B2P2TOOT for the facilities that have been provided, Sujarto as the supervisor of the garden, Danang Riyanto as the gardener.

\section{REFERENCES}

Astana PRW \& Nisa U. 2018. Analisis ramuan obat tradisional untuk wasir di Pulau Jawa; studi etnofarmakologi RISTOJA 2015. JIFI. 16(2): 115-123.

Balfas R, Mardiningsih TL, Sukmana C, \& Sartiami D. 2010. Pengaruh minyak tanaman obat dan aromatik terhadap mortalitas Doleschallia bisaltide pada tanaman daun wungu. In: Kardinan A, Laba IW, Kartohardjono A, Harnoto, Pudjianto, Winasa IW, Dadang, Rizal M, Ubaidillah R, Samudra IM, Ratna ES, Kusumawati U, Gunandini D, Sukartana P, Wiratno, Siswanto, Wahyono TE, \& Hamidi E (Eds.). Prosiding Seminar Nasional VI Perhimpunan Entomologi Indonesia. pp. 293298. Perhimpunan Entomologi Indonesia, Bogor.

Ballal CR. 2013. Other egg parasitoids: research for utilisation. In: Sithanantham S, Ballal CR, Jalali SK, \& Bakthavatsalam N (Eds.). Biological Control of Insect Pests Using Egg Parasitoids. pp. 223-270. Springer, New Delhi.

Barloggio G, Tamm L, Oberhänsli T, Nagel P, \& Luka H. 2015. The egg parasitoid Telenomus sp. as a novel biocontrol agent to prevent the cabbage moth. Acta fytotechn. zootechn. 18: 47-49.

Fauriah MR \& Anas S. 2019. Pengaruh jarak tanam dan varietas terhadap tingkat serangan hama utama pada tanaman jagung. Buletin Penelitian Tanaman Serealia. 3(1): 9-14.

Frago E, Pujade-Villar J, Guara M, \& Selfa J. 2012. Hyperparasitism and seasonal patterns of parasitism as potential causes of low top-down control in Euproctis chrysorrhoea L. (Lymantriidae). Biol. Control. 60(2): 123-131.

Gupta A, Saji K, \& Manoj P. 2016. Parasitoids of butterflies: reassignment of Dolichogenidea hasorae (Wilkinson, 1928) as a new combination along with new host-parasitoid linkages and notes on host specificity from Kerala, India. $J B C .30(2)$ : 61-67.
Handayani V, Dahelmi, \& Herwina H. 2019. Siklus hidup kupu-kupu Doleschallia bisaltide (Lepidoptera: Nymphalidae). Jurnal Education and Development. 7(3): 301-303.

Hasanah U, Dahelmi, Rizki A, \& Suwarno. 2018. Tabel kehidupan kupu-kupu Doleschallia bisaltide Cramer (Lepidoptera: Nymphalidae) yang dipelihara pada tanaman inang berbeda. Jurnal Bioleuser. 2(3): 59-62.

Hendrival, Hidayat P, \& Nurmansyah A. 2011. Kisaran inang dan dinamika populasi Bemisia tabaci (Gennadius) (Hemiptera: Aleyrodidae) di pertanaman cabai merah. J. HPT Tropika. 11(1): 47-56.

Hoskins A. 2012. Learn about Butterflies: the complete guide to the world of butterflies and moths. https:/ /www. learnaboutbutterflies.com/ About $\% 20$ the $\% 20$ author2.htm. Accessed on 1 February 2020.

James DG. 2017. The Book of Caterpillars: a Lifesize Guide to Six Hundred Species from Around the World. The University of Chicago Press, Chicago.

Lestari M, Widhiono I, \& Darsono. 2020. Keanekaragaman dan kemerataan spesies kupukupu (Lepidoptera: Nymphalidae ) di hutan cagar alam Bantarbolang, Pemalang, Jawa Tengah. BioEksakta: Jurnal Ilmiah Biologi Unsoed. 2(1): 16-22.

Lestari P, Khumaida N, Sartiami D, \& Mardiningsih TL. 2015. Selection criteria of Graptophyllum pictum resistance to Doleschallia bisaltide Cramer (Lep: Nymphalidae) attack based on insect feeding preference. SABRAO J. Breed. Genet. 47(2): 172-184.

Mardiningsih T, Sartiami D, Siswanto, \& Sukmana C. 2010. Parasitoid Doleschallia bisaltide (Lepidoptera: Nymphalidae) hama pemakan daun ungu. In: Kardinan A, Laba IW, Kartohardjono A, Harnoto, Pudjianto, Winasa IW, Dadang, Rizal M, Ubaidillah R, Samudra IM, Ratna ES, Kusumawati U, Gunandini D, Sukartana P, Wiratno, Siswanto, Wahyono TE, \& Hamidi E (Eds.). Prosiding Seminar Nasional VI Perhimpunan Entomologi Indonesia (PEI). pp. 482-491. PEI, Bogor. 
Muru D, Madl M, Jacquot M, \& Deguine JP. 2017. A literature-based review of Hymenoptera Parasitica and Chrysidoidea from Reunion Island. ZooKeys. 652: 55-128.

Nhestricia N, Rahminiwati M, Rustiani E, \& Dwiputri F. 2019. Perbandingan efektivitas analgetik ekstrak etanol dan ekstrak air daun ungu pada mencit (Mus musculus L.). FJIF. 9(2): 103-108.

Nitin R, Balakrishnan VC, Churi P V, Kalesh S, Prakash S, \& Kunte K. 2018. Larval host plants of the butterflies of the Western Ghats, India. J. Threat. Taxa. 10(4): 11495-11550.

Orr A \& Kitching R. 2010. The Butterflies of Australia. Allen \& Unwin, Jacana Books, Crows Nest.

Riyanto, Herlinda S, Irsan C, \& Umayah A. 2011. Kelimpahan dan keanekaragaman spesies serangga predator dan parasitoid Aphis gossypii di Sumatera Selatan. J. HPT Tropika. 11(1): 5768 .

Rizali A, Himawan T, Fitriani I, Rahardjo BT, Karindah S, Puspitarini RD, \& Sahari B. 2018. Effect of natural habitat on diversity of hemipteran predator in oil palm plantation. J. HPT Tropika. 18(1): 7582.

Sartiami D, Mardiningsih TL, Khumaida N, Kristina NN, \& Sukmana C. 2009. Doleschallia spp. (Lepidoptera: Nymphalidae) pada tanaman handeuleum (Graptophyllum pictum) di Indonesia. In: Nuryanto A, Budisantoso I, Ardli E, \& Prabowo R (Eds.). Seminar Nasional Peran Biosistematika dalam Pengelolaan Sumberdaya Hayati Indonesia. pp. 563-568. Fakultas Biologi Universitas Jenderal Soedirman, Purwokerto.
Shumakov EM. 1977. Ecological principles associated with augmentation of natural enemies. In: Ridgway R (Ed.). Biological Control by Augmentation of Natural Enemies: Insect and Mite Control with Parasites and Predators. pp. 39-78. Springer, New York.

Sujarweni VW. 2014. SPSS untuk Penelitian. Pustaka Baru Press, Yogyakarta.

Suryadi D, Megawati A, Susilo B, Dalimartha LN, Wiguna EC, Isdiantoni, Koentjoro MP, \& Prasetiyo EN. 2017. Model manajemen terpadu pertanian hortikultura organik pada lahan sempit. Proceeding Biology Education Conference. 14(1): 118-125.

Sya'haya S \& Iyos RN. 2016. Pengaruh pemberian ekstrak daun ungu (Graptophylum pictum Griff) terhadap penyembuhan hemoroid. Majority. 5(5): $155-160$.

Varshney RK \& Smetacek P. 2015. A Synoptic Catalogue of the Butterflies of India. New Delhi: Butterfly Research Centre, Bhimtal \& Indinov Publishing, New Delhi.

Widiyastuti Y, Haryanti S, Supriyati N, Katno, Sugiarso S, Damayanti A, Subositi D, Widayanti E, Ardiyanto D, Ismoyo SPT, Saryanto, Adi MBS, Fauzi, Widyastuti R, Kusumadewi AP, \& Listyana NH. 2012. Vademekum Tanaman Obat untuk Saintifikasi Jamu Jilid 1. Lembaga Penerbit Badan Penelitian dan Pengembangan kesehatan, Jakarta. 